\title{
Corruption and Debt Hangover: An Empirical Study of sub-Saharan Africa
}

\section{Nahid Kalbasi Anaraki}

Assistant Professor of Economics

Fort Hay State University

Hays, Kansas, United States

Email: nkanaraki@fhsu.edu

\section{United States}

\section{ABSTRACT}

This paper investigates the determinants of foreign debt for 25 countries in sub-Saharan Africa (SSA). Previous studies have emphasized factors such as oil price shocks, deteriorating terms of trade, rising public expenditures, and trade deficit as the main causes of debt hangover in SSA. This study uses a different approach, and measures the effects of corruption on debt through different regression models, and finds that the corruption index is significant in shaping debt hangover in sub-Saharan Africa. Also, the estimated results indicate that the corruption index plays a more important role compared to other macroeconomic fundamentals. The results also indicate that corruption has become a more significant post financial crisis of 2007 when several African countries faced with a new phase of debt forgiveness. Indeed, the results of this study suggest that debt forgiveness has entrapped SSA countries with more corruption, which has exacerbated the level of debt.

\section{Keywords: Balance of payments, budget deficit, corruption, debt, institutional reforms, macroeconomic fundamentals, terms of trade, Fixed Effect Model.}

\section{JEL Classification: E60, F34, F35, F40}

\section{Introduction}

Though several studies have investigated the causes of foreign debt in Africa, less attention has been paid to corruption and its effects on external debt. The massive external level of debt in Sub-Saharan Africa is a serious policy issue that needs further attention and new policy recommendations. Indeed, the etiology of the debt crisis has become so complicated that requires further scrutiny on the roots of the problem. This paper reviews the performance of debt for a group of sub-Saharan African countries and suggests a series of recommendations to reduce the level of debt.

Indeed, the high levels of debt to GDP among African countries has been attributed to two groups of variables: (i) domestic internal macroeconomic imbalances including the budget deficit, and inflation, and (ii) external imbalances such as terms of trade, trade deficit, and capital outflows. Though this group of countries has generally received foreign aids and debt forgiveness, they have been unable to pay back their debt on time and have been confronted with a huge amount of arrears that in most cases exceed $70 \%$ of their GDP. Though some of these countries have carried a series of economic reforms in response to international organization's requests, they have been unable to serve their debt on time, mainly due to chronic corruption that has undermined fiscal and monetary reforms.

The goal of this paper is twofold. First, it tries to measure the effects of corruption on foreign debt compared to other macroeconomic fundamentals, a question that has been barely addressed in the literature. Second, it tries to investigate whether debt forgiveness post-financial crisis of 2007-2009 has had any significant impact on the magnitude of corruption on the debt ratio.

The rest of the paper is organized as follows. Section 2 reviews the literature on the roots of the debt crisis in Africa and other regions. Section 3 portrays an empirical model for foreign debt and provides data description and methodology. Section 4 presents the estimated results using different econometric models and techniques. Finally, section 5 concludes and suggests policy recommendations to reduce the burden of debt.

\section{Literature review}

This section reviews the most important empirical studies that have been carried out on the determinants of the foreign debt crisis, particularly in Africa.

Among early studies, Danso (1990) categorizes the causes of Africa's debt crisis into two categories; (i) exogenous sources of debt in colonialism and the emergence of capitalism in developing countries. (ii) endogenous factors such as high birth rate, inefficient tax administration, and tax base, lack of saving base, insufficient investment, and pegged exchange rate regime that prevents the appropriate devaluation to encourage exports. He also refers to other mishaps and natural disasters such as drought and famine, which have contributed to the debt crisis in Africa. 
Ezenwe (1993) refers to the first oil price shock in 1973 and 1981. Also, he refers to the over-lending of the banks in 1982, the sudden withdrawal of the banks, and the highinterest rate in the international markets, which blew the debt crisis to African economies. In the meantime, domestic expansionary fiscal policy weakened their external position and led to a debt crisis. Given that most of these countries did not depreciate their currencies to offset the rise in inflation, their currencies became overvalued and this overvaluation hindered their external trade, exacerbating the debt problem.

Geda (2003) investigates the origins of Africa's foreign debt, which he attributes to the structure of its trade, oil shocks, recession in industrial countries, and a rise in realworld interest rates as major factors. He concludes that Africa's debt problem is a trade problem, which still shapes the external economic conditions of the continent.

Richards, Nwanna, \& Nwankwo (2003) indicate that debt relief is a process that requires containing capital flight and corruption. They believe capital outflow from corrupted leaders has played an important role in shaping foreign debt in Sub-Saharan Africa. They indicate the institutional process has created misallocation of resources and misappropriation of foreign aids and receipts.

Okeke (nd) discusses the effects of debt burden on African countries and the role of debt relief. He believes that African leaders must show sufficient determination and good faith in controlling public funds. A moratorium of at least ten years should be placed on foreign loans and when loans become inevitable, the donors should start to deal with NGOs and real representatives of people.

Briscoe (2006) investigates the debt problem in a group of African and Latin American countries. He believes one characteristic of the modern debt regime is the lack of a vertical mechanism of authority. Her refers to factors such as exchange rate regime, interest rate imposed on new bonds, and market imperfection as factors that affect foreign debt. He concludes some nations have been able to strengthen their autonomy by improving relations with the public at home and with foreign lenders, which has contributed to a lower level of debt and higher economic growth.

Elliott (nd) discusses corruption through the role of the state in the economy and its size; and refers to economic consequences of corruption including misallocation of resources, negative externalities, reduced government efficiency, and distortion of international trade. He proposes reforming institutions and incorporating transparency and accountability in the reform process and emphasizes the role of international financial institutions in this process. He concludes judicial reforms, institutional reforms, simplification of the tax system, strengthening NGOs, and institutions of civil society can help to combat chronic corruption in African countries.
Omotola \& Sailu (2009) investigate the African debt crisis with particular emphasis on Nigeria and refer to factors such as high export dependence, high concentration on a few commodities, declining terms of trade, and chronic balance of payment crisis. They believe that corruption of foreign aid regimes has contributed to the deterioration of foreign debt and this corruption constitutes serious challenges to the effectiveness of foreign aid in Africa.

Aluko \& Arowolo (2010) indicate that foreign debt was more than $42 \%$ of Africa's total capital inflow in 1980 . They refer to different factors that trapped African countries into debt crisis including a decline in prices of raw materials, deteriorating terms of trade, and a fall in foreign reserves.

Reinhart \& Rogoff (2010) use time-series data for 44 countries for over two hundred years and find that the relation between debt and GDP is weak. They find that when the external debt reaches $60 \%$ of GDP, annual growth drops by two percent, and for a higher level of debt, the growth rate falls in half.

Owoye \& Bissessar (2012) provide empirical evidence that bad governance and corruption are symptoms of leadership and institutional failure. They argue with a lack of checks and balances; corruption continues unabated over the past few decades. Their empirical results emphasize the weakness of institutions in controlling corruption and lingering effects of institutionalized corruption in many African countries have brought about lower growth and poverty.

Kamil \& Ishola (2015) investigate the impact of governance indices on economic growth in a group of selected sub-Saharan African countries for the period of 2002-2009. They find that political stability has growth-enhancing features. They find that despite several anti-corruption policies in the region, the impact of corruption on economic growth is not obvious. However, they find that if corruption is uncontrolled, it will undermine good governance and economic growth.

Ogunnoiki (2016) investigates the roots of the debt crisis in Nigeria. He refers to the oil shock, reckless lending of foreign banks, appetite of governments for commercial banks loans, low-interest rates, the balance of payments deficit, the decline in exports, and plummeting prices of agricultural products as main determinants of the debt crisis.

Kim, Ha, \& Kim (2017) investigate the effects of corruption on economic growth and debt crisis. They use panel data for 77 countries from 1990 to 2014 and implement OLS panel data, Fixed Effect, and Generalized Method of Moment (GMM) technique. Their results indicate that the interaction between public debt and corruption is statistically significant and confirm that the effects of public debt on economic growth are a function of corruption; however, debt enhances growth in countries that there is no corruption. 
Shittu, Hassan, \& Atif Nawaz (2018) examine the effects of external debt and corruption on economic growth in selected sub-Saharan African countries from 1990 to 2015. They find that there is a negative relationship between foreign debt and economic growth. Their findings also indicate a positive relationship between corruption and economic growth, with causality running from economic growth to corruption.

Coulibaly, Gandhi \& Senbet (2019) investigate the debt crisis in Africa and attribute the rapid increase in debt ratio to terms of trade shock in 2014 , low global interest rate, exchange rate depreciation, and poor governance. To overcome the debt problem, they propose a series of policy recommendations including boosting domestic resource mobilization, the lending capacity of development banks, commodity-linked sovereign debt, accelerating financial sector development, and capacity building.

Stiglitz \& Rashid (2020) propose several measures for averting debt hangover in Africa and Latin America including debt-restructuring mechanism, mitigating risk with private creditors, state-contingent debt contracts, and bankruptcy procedure.

Indeed, one of the shortcomings of the abovementioned studies is the lack of empirical study in measuring the effects of corruption on foreign debt through econometric techniques. The novel feature of this study compared to previous ones is that it measures the effects of

$$
\text { Debt }=a_{0}+a_{1} G D P+a_{2} \text { Open }+a_{3} I n f+a_{4} T o T+a_{5} B O P+a_{6} B D+a_{7} C F+a_{8} \text { Corr }
$$

\subsection{Data and sources}

Table 1. presents the list of variables, their definitions, and their sources. The data on the debt ratio comes from the Penn World Table. The data on GDP per capita, openness, CPI corruption on debt compared to macroeconomic fundamentals. It also investigates whether the forgiveness of debt has had any impact on the acceleration of the debt ratio.

\section{Empirical Analysis}

As mentioned before, the main goal of this study is to test whether corruption has a significant impact on debt that is more important compared to macroeconomic fundamentals. To test this hypothesis, we provide an empirical model, data, list of variables, and methodology in this section. The paper implements time series data for the period of 1990-2018 using three different econometric techniques (i) the standard panel regression model of OLS, (ii) the Fixed Effect Model, and (iii) the Generalized Method of Moment (GMM). The fixed Effect model is appropriate because we focus on a group of specific countries in SSA that have been confronted with high debt ratios. The list of African countries is provided in Appendix-1.

\subsection{Model Specification and Estimation}

\section{Methodology}

To estimate the effects of corruption on debt compared to macroeconomic fundamentals we expand the model introduced by Kim, Ha, \& Kim (2017). We use several macroeconomic fundamentals besides the corruption index to measure the effect of each variable on the debt ratio. We expect corruption has a positive significant impact on the debt ratio.

\section{Table 1. Variables and Data Sources}

\begin{tabular}{|l|l|l|}
\hline $\begin{array}{l}\text { Variable } \\
\text { Name }\end{array}$ & Definition & Source \\
\hline Debt & Ratio of foreign debt to GDP & Penn World Table \\
\hline GDP & Gross Domestic Production Per Capita & World Bank \\
\hline Open & Openness: (Import + Exports)/GDP & Penn World Table \\
\hline Inf & CPI inflation rate & World Bank \\
\hline TOT & Terms of Trade & World Bank \\
\hline BOP & Balance of Payments & World Bank \\
\hline BD & Ratio of Budget Deficit to GDP & World Bank \\
\hline CF & Net Capital Flow & World Bank \\
\hline Corr & Corruption Index & Transparency International \\
\hline Dummy & Dummy variable for forgiveness of debt & Post 2007 (1) \\
\hline
\end{tabular}

Table 2. presents the descriptive statistics for the full mean of this variable for our sample is 4.5 and the standard sample of 25 countries. The corruption index runs from 1 to deviation is 2.63 , which shows there is enough variation in the 10; the bigger the score the less corrupted the country is. The corruption level among sample countries. 
Table 2. Descriptive Statistics for Sample of 25 Countries

\begin{tabular}{|l|l|l|l|l|}
\hline Variable Name & Mean & Std. Dev. & Min & Max \\
\hline Debt & 0.75 & 0.35 & 0.01 & 2.56 \\
\hline GDP & 18730 & 16.41 & 624 & 64250 \\
\hline Open & 0.63 & 0.59 & 0.07 & 2.17 \\
\hline Inf & 12.34 & 2.30 & 1.15 & 27.13 \\
\hline TOT & 5.64 & 1.23 & 2.17 & 8.56 \\
\hline BOP & 23650 & 19.23 & 234 & 84320 \\
\hline BD & 0.65 & 0.045 & -0.218 & 0.75 \\
\hline CF & 2680 & 14.36 & -2461 & 9843 \\
\hline Corr & 4.5 & 2.63 & 1.10 & 10.00 \\
\hline
\end{tabular}

\section{Estimated results}

Table 3 presents the estimated results using panel data regression with OLS (column 1), the Fixed Effect Model (column 2), and the Generalized Method of Moment (Column 3). As shown in this Table all models have an R-squared of higher than $80 \%$, which means all independent variables have been able to explain more than $80 \%$ of changes in the debt ratio. The results suggest that openness, terms of trade, budget statistically significant impacts on the debt ratio. However, the corruption index has a more statistically significant impact on the debt ratio compared to other macroeconomic fundamentals. Interestingly enough, the results are consistent when we use different estimation techniques as in all cases the effects of corruption are more significant than other macroeconomic fundamentals. The estimated results emphasize the importance of corruption on the debt burden in sub-Saharan Africa.

Table 3. Estimated Results for Foreign Debt in 25 African Countries

\begin{tabular}{|l|l|l|l|}
\hline Variables & OLS & Fixed Effect Model & GMM \\
\hline GDP & 0.03 & 0.04 & 0.07 \\
& $(0.002)$ & $(0.017)$ & $(0.014)$ \\
\hline Open & $0.21^{* *}$ & $0.20^{* *}$ & $0.17 *$ \\
& $(0.026)$ & $(0.032)$ & $(0.027)$ \\
\hline Inf & 0.04 & 0.06 & 0.07 \\
& $(0.001)$ & $(0.002)$ & $(0.05)$ \\
\hline TOT & $0.07 * *$ & $0.12^{* *}$ & $0.09 * *$ \\
& $(0.0018)$ & $(0.006)$ & $(0.003)$ \\
\hline BOP & $0.02 * *$ & $0.04 *$ & $0.05 * *$ \\
& $(0.0013)$ & $(0.002)$ & $(0.003)$ \\
\hline BD & $0.13 * *$ & $0.14 *$ & $0.14 *$ \\
& $(0.001)$ & $(0.002)$ & $(0.025)$ \\
\hline CF & $0.22 *$ & $0.27 *$ & $0.26 *$ \\
& $(0.0017)$ & $(0.002)$ & $(0.0021)$ \\
\hline Corr & $0.34 * * *$ & $0.37 * * *$ & $0.41^{* * *}$ \\
& $(0.0012)$ & $(0.0015)$ & $(0.0021)$ \\
\hline R-Squared & 0.86 & 0.81 & - \\
\hline
\end{tabular}

To test whether there is any structural change in the because several of these countries faced with forgiveness after effects of corruption post-financial crisis, a period identified the great recession. The results suggest that the coefficient of with debt forgiveness for several African countries, we divide corruption has significantly increased during the second subour sample into two sub-periods 1990-2007 and 2007-2018 period, which means debt forgiveness has plunged the African 


\section{(C) Center for Promoting Education and Research (CPER) USA}

WWW.cpernet.org

countries into more debt. We also use a dummy variable for those years ( 1 for post-2007 and zero for the rest) and find that the coefficient of the dummy variable is statistically significant, meaning that the debt forgiveness has increased the debt ratio post-financial crisis. Our results here are consistent with those of Omotola \& Sailu (2009) and Kim, Ha, and Kim (2017) who believe corruption is one of the main roots of debt hangover in Africa.

Table 4. Estimated Results for Foreign Debt during two sub-periods

\begin{tabular}{|c|c|c|c|c|}
\hline Variables & $\begin{array}{l}\text { 1990-2018 } \\
\text { OLS }\end{array}$ & $\begin{array}{l}\text { 1990-2018 with } \\
\text { dummy }\end{array}$ & $\begin{array}{l}1990-2007 \\
\text { Sub-period } 1\end{array}$ & $\begin{array}{l}2007-2018 \\
\text { Sub-period } 2\end{array}$ \\
\hline GDP & $\begin{array}{l}0.03 \\
(0.002)\end{array}$ & $\begin{array}{l}0.027 \\
(0.0017)\end{array}$ & $\begin{array}{l}0.12 \\
(0.0017)\end{array}$ & $\begin{array}{l}0.14 \\
(0.0021)\end{array}$ \\
\hline Open & $\begin{array}{l}0.21 * \\
(0.026)\end{array}$ & $\begin{array}{l}0.24 * \\
(0.017)\end{array}$ & $\begin{array}{l}0.20^{*} \\
(0.0014)\end{array}$ & $\begin{array}{l}0.17 * \\
(0.0012)\end{array}$ \\
\hline Inf & $\begin{array}{l}0.04 * \\
(0.001)\end{array}$ & $\begin{array}{l}0.06^{*} \\
(0.017)\end{array}$ & $\begin{array}{l}0.06^{* *} \\
(0.001)\end{array}$ & $\begin{array}{l}0.07 * \\
(0.003)\end{array}$ \\
\hline TOT & $\begin{array}{l}0.07 * * \\
(0.018)\end{array}$ & $\begin{array}{l}0.07 * \\
(0.017)\end{array}$ & $\begin{array}{l}0.12 * * \\
(0.0013)\end{array}$ & $\begin{array}{l}0.09 * * \\
(0.0024)\end{array}$ \\
\hline BOP & $\begin{array}{l}0.02 * * \\
(0.0013)\end{array}$ & $\begin{array}{l}0.03 * * \\
(0.0012)\end{array}$ & $\begin{array}{l}0.04 * * \\
(0.006)\end{array}$ & $\begin{array}{l}0.05^{* *} \\
(0.0017)\end{array}$ \\
\hline $\mathrm{BD}$ & $\begin{array}{l}0.13^{*} \\
(0.001)\end{array}$ & $\begin{array}{l}0.015^{*} \\
(0.001)\end{array}$ & $\begin{array}{l}0.14^{*} \\
(0.0021)\end{array}$ & $\begin{array}{l}0.14 * \\
(0.0037)\end{array}$ \\
\hline $\mathrm{CF}$ & $\begin{array}{l}0.22^{*} \\
(0.0017)\end{array}$ & $\begin{array}{l}0.19 * \\
(0.0012)\end{array}$ & $\begin{array}{l}0.27 * \\
(0.0014)\end{array}$ & $\begin{array}{l}0.26^{*} \\
(0.0023)\end{array}$ \\
\hline Corr & $\begin{array}{l}0.34 * * * \\
(0.0012)\end{array}$ & $\begin{array}{l}0.37 * * * \\
(0.0011)\end{array}$ & $\begin{array}{l}0.32 * * * \\
(0.0027)\end{array}$ & $\begin{array}{l}0.41 * * * \\
(0.0035)\end{array}$ \\
\hline Dummy & & $\begin{array}{l}0.14 * * \\
(0.001)\end{array}$ & & \\
\hline R-Squared & 0.86 & 0.85 & 0.81 & 0.82 \\
\hline F-Statistics & 123.48 & 314.23 & 156.21 & 164.79 \\
\hline D.W. & 2.31 & 2.18 & 2.24 & 2.13 \\
\hline
\end{tabular}

Indeed, our results in Table 4 indicate that as we divide the sample into two sub-periods the magnitude of corruption coefficient increases during the post-financial crisis of 2007 from 0.32 to 0.41 . The results indicate that more forgiveness has intensified the effects of corruption on foreign debt. Alternatively, we used a dummy variable for the years that sample countries have faced forgiveness and found that the coefficient on the dummy variable is statistically significant, which suggests the higher the level of forgiveness, the higher the level of corruption, and the higher the level of foreign debt. That is how several sub-Saharan African countries entrapped to debt hangover.

\section{Conclusion and Policy Recommendation}

Foreign debt has been a chronic disease for a big number of African countries during several past decades. The literature on the topic has mainly focused on the negative effects of macroeconomic fundamentals such as the budget deficit, balance of payment deficits, inflation, capital outflow, and terms of trade. Indeed, a few studies have emphasized corruption, and generally in a qualitative manner.

Lack of empirical studies on estimating the effects of corruption on foreign debt in the literature, induced us to investigate how corruption has affected the debt ratio compared to other macroeconomic fundamentals. We also aimed to address whether debt forgiveness has had any impact 
on the debt ratio. Using three different econometric techniques OLS panel data, Fixed Effects Model, and Generalized Method of Moments (GMM), the estimated results show that interaction between debt and corruption is statistically significant and more important than other macroeconomic fundamentals. We divided the data into two sub-periods 19902007 and 2007-2018 to test whether the post-2007 financial crisis period, identified as the debt forgiveness period, has intensified the effects of corruption on debt. The estimated results for these two sub-periods indicate that the effects of corruption have significantly increased during the postfinancial crisis of 2007 with debt forgiveness.

Indeed, we believe that debt forgiveness and lack of checks and balances, and institutional inefficiency on controlling the use of foreign aids and forgiveness has led to a higher level of corruption and a higher level of debt, which highlights the importance of the role of advanced economies in controlling debt. Indeed, advanced countries should implement better strategies to help African countries to overcome the debt crisis. Debt forgiveness does not seem to be an efficient mechanism to reduce the debt burden and corruption. Contrary, the estimated results in this study indicate that more debt forgiveness has brought more corruption and led to a higher level of debt. Therefore, we believe advanced economies can play an important role in reducing the debt burden in Africa by requiring new reforms and checks and balances.

Among strategies that advanced economies may use instead of debt, forgiveness is to provide humanitarian aids through NGOs and real representatives of people rather than helping the corrupt governments because the estimated results of this study cast doubt on the effectiveness of debt forgiveness and foreign aids. Another effective strategy is to use a threshold for the level of corruption index and tie debt forgiveness to the corruption index. If a country has a high corruption index it shouldn't be able to receive the aid or enjoy debt forgiveness. Though several African countries are currently in need of more aid to overcome their economic challenges, particularly with the pandemic effects, the aid should be provided in a manner to avoid more corrupt governments. Indeed, policymakers should make sure that the good governance and low corruption index is in place before taking any action toward debt forgiveness for sub-Saharan Africa. Indeed, though several of these countries have been required by international financial organizations to carry out structural reforms to receive aid and forgiveness, they still lack an efficient plan to reduce the corruption index, mainly due to lack of efficient institutions, big government, and absence of NGOs. The advanced economies policymakers can help these countries to avoid these obstacles not only by offering money and forgiveness but through technical assistance and checks and controls.

This study can be expanded in the future in several ways. One way to expand the study is by incorporating good governance besides the corruption index into the model to see how good governance affects the level of debt. Another way to expand the study is to include all countries in the region in the sample and expand the data to cover more decades.

\section{Conflict of Interest:}

The authors declare no conflict of interest.

Funding:

This work has no received any specific grant.

\section{References}

Aluko, F. \& Arowolo, D. (2010). Foreign Aid, the Third World's Debt Crisis and the implication for Economic Development: The Nigerian Experience, African Journal of Political Science and International Relations Vol 4 (44), 120-127.

Briscoe, I. (2006). Debt Crisis, Political Change and the State in Developing World, Instituto Complutense de Estudies Internationale (ICEI) Working Paper 01/06, retrieved from: https://www.ucm.es/data/cont/docs/430-2013-10-272006\%20WP\%2001-06.pdf

Coulibaly, B.S., Gandhi, D., Senbet L. (2019), Is sub-Saharan Africa Facing Another Systemic Sovereign Debt Crisis? Brooking Institute, Africa Growth Initiative, Policy Brief, retrieved from https://www.brookings.edu/wpcontent/uploads/2019/04/africa sovereign debt sustainability.pdf

Danso, A. (1990). The Debt Crisis and Africa's Maldevelopment, Politics and Policy, https://onlinelibrary.wiley.com/doi/pdf/10.1111/j.1747-1346.1990.tb00294.x

Elliot, K. A. (nd) Corruption as an International Policy Problem: Overview and Recommendations, Institute for International Economics, retrieved from: https://www.piie.com/publications/chapters preview/12/10iie2334.pdf

Ezenwe, Uka (1993) : The african debt crisis and the challenge of development, Intereconomics, ISSN 0020-5346, Nomos Verlagsgesellschaft, Baden-Baden, Volume 28 (1), 35-43, http://dx.doi.org/10.1007/BF02928100 
Greene J. (1989). The External Debt Problem of Sub-Saharan Africa, Staff Papers (International Monetary Fund) 36 (4), 836-874, https://doi.org:10.2307/3867242.

Geda, A. (2003). The Historical Origin of African Debt Crisis, Eastern Africa Social Science Research Review 19 (1), 59 89. Doi: https://doi.org/10.1353/eas.2002.0012

Kamil, O. \& Ishola, M. H. (2015). Corruption, Governance, and Economic Growth in Sub-Saharan Africa: A need for prioritization of reform policies, Coventry University, UK, retrieved from https://curve.coventry.ac.uk/open/file/3aa299e4-2f95-4460-947d-c3ae2b5fb7b5/1/omotesocomb.pdf

Kim, E., Ha, Y. \& Kim, S. (2017). Public Debt, Corruption, and Sustainable Economic Growth, Sustainability 9, 433; Https://doi.org:10.3390/su903043

Mustapha, S. \& Prizzon, A. (2018). Africa's Rising Debt: How to Avoid a New Crisis, ODI briefing note, London.retrieved from https://www.odi.org/sites/odi.org.uk/files/resource-documents/12491.pdf

Omotola, J.S. \& Sailu, H. (2009). Foreign Aid, Debt Relief, and Africa's Development: Problems and Prospects, South African Journal of International Affairs, Vol 16 (1), 87-102.

Ogunnoiki, A. O. (2016). The Sovereign Debt Crisis in Africa and its impacts on African states economic growth and development. A Case Study of Nigeria, Ideal Journal of Arts and Humanities 2(3), 103-114.

Okeke, C. N. (nd) The Debt Burden: An African Perspective, The International Lawyer, Volume 35, No.4. retrieved from https://core.ac.uk/download/pdf/216909854.pdf

Owoye, O., \& Bissessar, N. (2012). Bad Governance and Corruption in Africa: Symptoms of Leadership and Institutional Failure, Trust Africa Organization, retrieved from:

http://iffoadatabase.trustafrica.org/iff/bad governance and corruption in africa symptoms of leadership and instituti onal_failure.pdf

Reinhart, C.M, \& Rogoff, K. S. (2010). Growth in Time of Debt, American Economic Review (100), 5730578.

Richards, D., Nwanna, G. \& Nwankwo, S. (2003) Debt Burden and Corruption Impacts: African Market Dynamism, Management Decision, Volume 41(3), 304-310.

Shittu, W., Hassan, S. \& Atif Navaz, M. (2018). The Nexus between External Debt, Corruption and Economic Growth: Evidence from Five SSA Countries, African Journal of Economic and Management Studies 9 (3), https://doi.org 10.13140/RG.2.2.34157.69605

Stiglitz, J. \& Rashid, H. (2020). Averting Catastrophic Debt Crises in Developing Countries, Extraordinary Challenges Call for Extraordinary Measures, Columbia University, retrieved from:

https://cepr.org/sites/default/files/policy_insights/PolicyInsight104.pdf

Woo, j. \& Kumar, M.S. (2015). Public Debt and Growth. Economica, 82, 705-739.

\section{Appendix .1}

Table 1. List of African Countries used in the study

\begin{tabular}{|c|c|c|c|c|}
\hline Angola & Ethiopia & Liberia & Niger & Somalia \\
\hline Benin & Gabon & Mali & Nigeria & South Africa \\
\hline Cameroon & Gambia & Mauritania & Senegal & Tanzania \\
\hline Chad & Ghana & Mozambique & Sierra & Uganda \\
\hline Cote d'Ivoire & Kenya & Namibia & Leone & Zambia \\
\hline
\end{tabular}

